\title{
Elderly Abuse and Care of the Aged in Nigerian Society: A Case Study of Old People's Home Yaba
}

\author{
Osunderu Oluwakemi* and Abimbola Elizabeth Adeyoyin \\ Federal College of Complementary and Alternative Medicine, Nigeria \\ *Corresponding author: Osunderu Oluwakemi, Federal College of Complementary and Alternative Medicine, Abuja, Nigeria
}

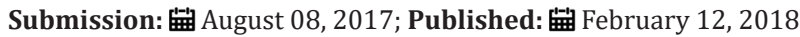

\begin{abstract}
Neglect is the most common elder abuse we have. It includes failure to provide necessary care, refusal or failure to fulfill any part of an obligation or duties to an elderly person. It simply means the refusal or failure to provide the aged with such life necessities as foods, water, clothing, shelter, personal hygiene, medicine, comfort, personal safety and social activities. This research has helped to emphasize the importance of medical, social care givers and administrators of old people's home. The research work is based on three variables; the comparism between aged living at the nursing homes to those living with their family members; the government activities and policies and its impact in caring for the aged; the importance of professional care givers such as medical professionals, social care givers and other trained service givers to the aged as they are also being needed by children and pregnant women [1].

From the hypothesis analyzed, it was discovered that the percentage of those who do not see any significant reason in keeping aged people in nursing homes are more than those who thought it fit to keep them in the homes. The percentage of those who accepted the keeping of aged in elderly homes is $40.5 \%$ to those who do not accept which stands at 59.5\%. The null hypothesis is therefore acceptable for further studies. Hence, there is no significant difference between the cares of the elderly in the old people's home and the family taken care of their aged in Nigeria. This work establishes that for effectiveness in caring for our aged citizens; we need to upgrade the nursing homes with qualified care givers who have passions for elderly welfare [2]
\end{abstract}

\section{Reseach Questions and Hypothesis}

As a result that the aged care needs to be intensify, the following questions comes to mind:

\section{A. What kind of elder abuse usually prevails?}

B. Do elderly homes exist in Nigeria?

C. Is care home an important institution to our society?

D. What kind of influence do the government and the society have on the care of aged in Nigeria?

Therefore for the purpose of this research work, the following Hypothesis will be tested to make state of fact about the work at hand.

\section{Hypothesis one}

There is no significant difference between the care of the elderly in the old people's home and the traditional care given to them by their family [3].

\section{Hypothesis two}

There is no significant impact of the social policy guiding the care of the elderly.

\section{Hypothesis three}

There is no significant attention needed by the aged in terms of medical, social care, and other services compared to children and pregnant women.

\section{Research Design}

This research aims at knowing the better way elderly care could be carried out in Nigeria, and how to reduce elderly abuse in our society. For understanding and clarity of the project, certain elements are under listed for study the study design. These are: Population and Sampling Procedures; Research Instrument; Instrument Validity; Administration of the research Instrument; Scoring and Data Analysis [4].

\section{Characteristics of the study population}

A total number of 90 questionnaires were distributed, out which 84 were returned. Therefore a total number of 84 respondents were worked upon. The responses were presented as tables, bar chart, and pie chart. The questionnaires are divided into sections A and B. Section A deals with Biographical data, which include sex, marital status, age range, religion, ethnicity, educational status, and occupation. Section B was designed in a Liker form of 
questionnaire. There were three types designed according to the hypothesis of the study. The first questionnaire (B1) was designed for the aged people in the nursing homes and those who are being cared for by their family relations. The second one was designed for general populace to detect the effectiveness of government policies in taking care of the aged in Nigeria. While the third questionnaire (B3) was designed for medical professional and other care givers, to determine the need for care for aged like children and women [5].

\section{Data collection instrument}

The instrument that was used for this research was a questionnaire designed to provide answers to the hypothesis raised towards the abuse and care of aged in Nigerian society. The questionnaire was developed to obtain information from the selected respondents consisting of sections A and B respectively. Section A deals with Biographical data which includes sex, age range, marital status, religion, ethnicity, occupation, educational status and number of children etc. Section B is based on Likerttype with four options namely, Strongly Agree (SA); Agree (A); Strongly Disagree (SD); Disagree (D). This section contains 15 items of statements asking information from selected respondents. The responses collected were analyzed statistically, presented by frequency, percentages, bar charts and pie charts [6]

Analysis

\section{Analysis of data in section A}

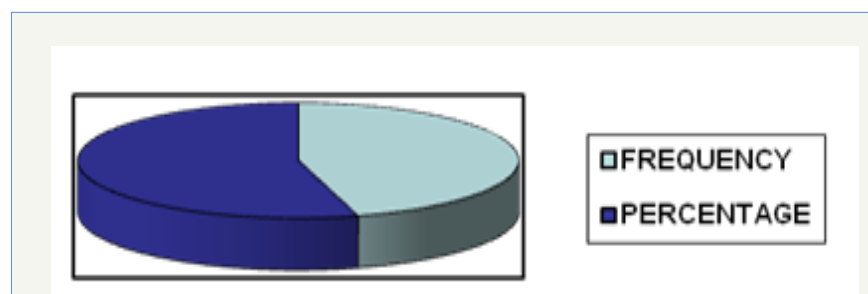

Figure 1: Showing respondent distribution based on sex.

(Figure 1) The figure above shows that 51.2\% (43) of the respondents were female while $48.8 \%$ (41) of the respondents were male (Table 1).

Table 1: Showing distribution of respondents by age.

\begin{tabular}{|c|c|c|}
\hline Age Range in Year & Frequency & Percentage \% \\
\hline$<50$ & 45 & 53.6 \\
\hline $50-59$ & 13 & 15.5 \\
\hline $60-69$ & 4 & 4.8 \\
\hline $70-79$ & 6 & 7.1 \\
\hline $80-89$ & 12 & 14.3 \\
\hline 90 \& above & 4 & 4.8 \\
\hline Total & 84 & 100 \\
\hline
\end{tabular}

From the above table, it shows that respondents who belongs to the age group below 50 years were $45(53.6 \%), 50$-59 years were $13(15.5 \%), 60-69$ years were $4(4.8 \%), 70-79$ years were $6(7.1 \%)$, $80-89$ year were $12(14.3 \%)$ and 90 years above were $4(4.8 \%)$ (Figure 2,3). So in the table above, ages below 50 years have the highest frequency and percentage [7]

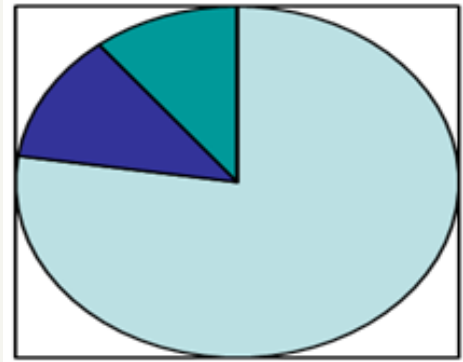

口YORUBA

口IGBO

口OTHERS

Figure 2: Showing respondent distribution on ethnicity.

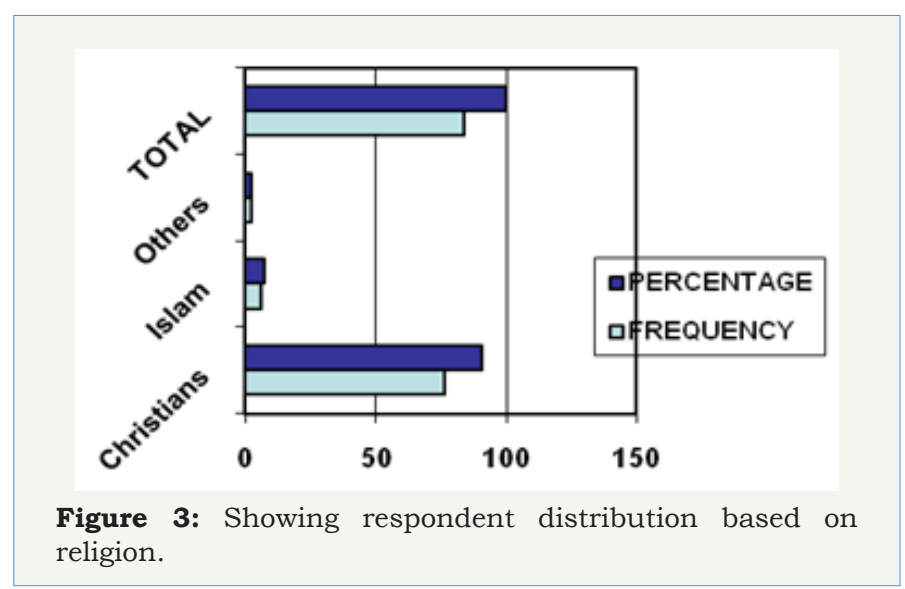

\section{Analysis of data in section B}

Hypothesis one: There is no significant difference between the care of the elderly in the old people's home and the traditional care given to them by their family. To test this Hypothesis, the scores from the aged respondents were analyzed and grouped into two variables. The variables were those who agreed, strongly agreed and those who disagreed, and strongly disagreed.

Key

A = Strongly Agree and Agree

$\mathrm{D}=$ Strongly Disagree and Disagree

Total Percentage $=$ Total A/Total A \& D * 100/1

$$
\begin{aligned}
& A=135 / 333 * 100 / 1=40.5 \% \\
& D=198 / 333 * 100 / 1=59.5 \%
\end{aligned}
$$

Table 2 above, shows that the percentage of those who disagree with the hypothesis that "There is no significant difference between care of the elderly in the old people's home and the traditional care given to them by their family" is more than those who agrees with the hypothesis. 
Table 2: Test of difference between aged people who agreed and disagreed about the use of elderly homes to traditional care, given by the family.

\begin{tabular}{|c|c|c|c|c|c|}
\hline & & A & & D & \\
\hline SN & & Frequency & $\%$ & Frequency & $\%$ \\
\hline 1 & Elderly Home is very important in our society & 24 & 80 & 6 & 20 \\
\hline 2 & It is more effective to keep elders in Nursing Homes & 12 & 40 & 18 & 60 \\
\hline 3 & Elderly Home is acceptable to our culture & 8 & 26.6 & 22 & 73.3 \\
\hline 4 & Elderly Homes reduce relations stress of caring for aged & 28 & 93.3 & 2 & 6.6 \\
\hline 5 & $\begin{array}{c}\text { Modern day Elderly Homes helps to solve the problems associated with ageing } \\
\text { process }\end{array}$ & 22 & 73.3 & 8 & 26.6 \\
\hline 6 & I personally prefers Elderly Home to traditional way of caring for aged & 12 & 40 & 18 & 60 \\
\hline 7 & $\begin{array}{l}\text { In traditional context, Elderly Homes does not allow intimacy between the aged } \\
\text { and their relations }\end{array}$ & 26 & 86.7 & 4 & 13.3 \\
\hline 8 & Elderly Homes does not necessarily increases aged intimacy with peers & 18 & 60 & 12 & 40 \\
\hline 9 & Keeping aged in Elderly Homes does not signify neglect on the part of the relations & 20 & 66.7 & 10 & 33.3 \\
\hline 10 & Keeping aged in Nursing Homes does not portend adequate care & 14 & 46.7 & 16 & 53.3 \\
\hline 11 & The way and manner the Elderly Home is been run in Nigeria is highly encouraging & 10 & 33.3 & 18 & 60 \\
\hline 12 & Keeping a good elderly home can reduce early death rate among ageing & 22 & 73.3 & 8 & 26.6 \\
\hline 13 & I personally prefer aged been cared for by their family relations & 24 & 80 & 6 & 20 \\
\hline 14 & $\begin{array}{l}\text { There is no difference between keeping the aged in the Elderly Homes to keeping } \\
\text { them within the reach of the relations }\end{array}$ & 8 & 26.6 & 22 & 73.3 \\
\hline \multirow[t]{2}{*}{15} & Elderly Home is the solution to elderly neglect & 22 & 73.3 & 8 & 26.6 \\
\hline & Total & 135 & 40.5 & 198 & 59.5 \\
\hline
\end{tabular}

Hypothesis Two: There is no significant impact of the social policy guiding the care of the elderly. To test this hypothesis, the scores from the respondents were analyzed and grouped into Agreed and Disagreed using Frequency and Percentages.

\section{Key}

A = Agreed \& Strongly Agreed.
D = Disagreed \& Strongly Disagreed.

$\mathrm{F}=$ Frequency.

Total Percentage $=$ Total A $/$ Total A \& D * 100/1

Table 3: Test of impact of social policies guiding the care of the aged.

\begin{tabular}{|c|c|c|c|c|c|}
\hline SN & & & A & & D \\
\hline & & $\mathbf{F}$ & $\%$ & $\mathbf{F}$ & $\%$ \\
\hline 1 & Elderly Home exists in Nigeria & 27 & 90 & 3 & 10 \\
\hline 2 & Elderly Homes in Nigeria is in good state & - & - & 30 & 100 \\
\hline 3 & Elderly Homes in Nigeria are built to world standard & - & - & 30 & 100 \\
\hline 4 & Elderly Homes are necessary in Nigeria. & 27 & 90 & 3 & 10 \\
\hline 5 & Nigerian government plays important role in establishment of Elderly Homes in Nigeria. & 9 & 30 & 21 & 70 \\
\hline 6 & The Nigerian government is highly involved in financing Elderly Homes in Nigeria & 9 & 30 & 21 & 70 \\
\hline 7 & The Nigerian Government encourages her citizen to patronize Elderly Homes. & 3 & 10 & 27 & 90 \\
\hline 8 & The Nigerian government has policy guiding the care of Elderly in Nigeria. & 12 & 40 & 18 & 60 \\
\hline 9 & The pension scheme in Nigeria is been adequately administered with elderly in mind. & - & - & 30 & 100 \\
\hline 10 & The Elderly in Nigeria lives longer than any other part in Africa. & - & - & 30 & 100 \\
\hline 11 & There are adequate trained hands in Elderly Homes in Nigeria. & - & - & 30 & 100 \\
\hline 12 & The Nigerian government encourages privately owned Elderly homes & 12 & 40 & 18 & 60 \\
\hline 13 & The government owned Elderly Homes are better managed than privately owned Homes & - & - & 30 & 100 \\
\hline 14 & $\begin{array}{c}\text { Most of the privately owned Elderly Homes in Nigeria are established by religious } \\
\text { organizations }\end{array}$ & 24 & 80 & 6 & 20 \\
\hline \multirow[t]{2}{*}{15} & Pension schemes in Nigeria need to be improved upon & 27 & 90 & 3 & 10 \\
\hline & Total & 150 & 33.3 & 300 & 66.7 \\
\hline
\end{tabular}

How to cite this article: Osunderu O, Abimbola E A. Elderly Abuse and Care of the Aged in Nigerian Society: A Case Study of Old People's Home Yaba. Gerontol \& Geriatric stud. 2(1). GGS.000530. 2018. DOI: 10.31031/GGS.2018.02.000530 
Table 3 above shows that the number of respondents who believes that, "There is no significant impact of the social policies guiding the care of the elderly" is higher, thereby supporting the Hypothesis formulated.

Hypothesis three: There is no significant attention needed by the aged in terms of medical, social care, and other services compare to children and pregnant women. To Test this Hypothesis, the scores from the respondents were analyzed and grouped into Agreed \& Disagreed using frequency and percentage.

\section{Key}

A = Agreed \& Strongly Agreed.
D = Disagreed \& Strongly Disagreed.

$\mathrm{F}=$ Frequency

Total Percentage $=$ Total A/Total A \& D * 100/1

$A=213 / 3547 * 100 / 1=59.7 \%$

$\mathrm{D}=144 / 357 * 100 / 1=40.3 \%$

Table 4 above shows that the number of respondents who agrees that Aged also need medical, social care, and other services like children and pregnant women is higher. Hence, reject the hypothesis, and support elderly care just like children and pregnant women [8].

Table 4: Test of significant attention needed by the aged in terms of medical, social, and other services compared to children and pregnant women.

\begin{tabular}{|c|c|c|c|c|c|}
\hline & & & A & & D \\
\hline SN & & $\mathbf{F}$ & $\%$ & $\mathbf{F}$ & $\%$ \\
\hline 1 & Existence of Elderly Homes is very important in Nigeria & 21 & 87.5 & 3 & 12.5 \\
\hline 2 & The aged in Nigeria are highly abused due to lack of adequate care & 18 & 75 & 3 & 12.5 \\
\hline 3 & The state of Elderly Homes in Nigeria is in a deplorable state & 18 & 75 & 6 & 25 \\
\hline 4 & Elderly Homes in Nigeria is built up to world standard & 3 & 12.5 & 21 & 87.5 \\
\hline 5 & Human resources needed for Elderly Homes is adequate & - & - & 24 & 100 \\
\hline 6 & Trained Nurses should be encouraged to take up elderly Home job & 24 & 100 & - & - \\
\hline 7 & Only trained medical personnel's can take good care of the Elderly & 6 & 25 & 18 & 75 \\
\hline 8 & $\begin{array}{l}\text { Modern day Nursing Homes for Aged is the solution to solving the management of problems } \\
\text { associated to ageing process }\end{array}$ & 18 & 75 & 6 & 25 \\
\hline 9 & Untrained medical personnel can equally take good care of Elderly & 21 & 87.5 & 3 & 12.5 \\
\hline 10 & More Nigerians have come to realize the need for establishing Elderly nursing homes & 15 & 62.5 & 9 & 37.5 \\
\hline 11 & $\begin{array}{c}\text { More Nigerians have come to realize the importance of health officials especially nurses in } \\
\text { Elderly Homes }\end{array}$ & 15 & 62.5 & 9 & 37.5 \\
\hline 12 & $\begin{array}{c}\text { There are lots of quack nurses usurping the roles of trained nurses in taking care of aged in } \\
\text { Nigeria }\end{array}$ & 24 & 100 & - & - \\
\hline 13 & $\begin{array}{c}\text { There is no need for government policy on establishing and equipping elderly homes with } \\
\text { professional health officials }\end{array}$ & 6 & 25 & 18 & 75 \\
\hline 14 & There is no difference in medical practitioners taking care of elderly to family relations & 9 & 37.5 & 15 & 62.5 \\
\hline \multirow[t]{2}{*}{15} & Elderly abuse supersede elderly care in Nigeria & 15 & 62.5 & 9 & 37.5 \\
\hline & Total & 213 & 59.7 & 144 & 40.3 \\
\hline
\end{tabular}

Summary, Conclusions and Recommendations

\section{Summary}

The discussion is based on the data collected from the old people's home Yaba, medical professionals and care givers and randomly picked general populace within the city of Lagos, Nigeria. The findings are divided into sections A and B. While section A deals with biographical data of respondents, section B dwelt on Hypothesis formed by the researchers.

Hypothesis one: The Hypothesis states that, "There is no significant difference between the care of the elderly in the old people's home and the Traditional care given to them by their family". From the hypothesis analyzed, it was discovered that the percentage of those who do not see any significant reason in keeping aged people in nursing homes are more than those who thought it fit to keep them in the homes. The percentage of those who accepted the keeping of aged in elderly homes is $40.5 \%$ to those who do not accept which stands at $59.5 \%$. The null hypothesis is therefore acceptable for further studies. Hence, there is no significant difference between the cares of the elderly in the old people's home and the family taken care of their aged in Nigeria. While the researchers were having verbal discussions with the inmates at Yaba old people's home, majority of them complained of neglect by their family members. This finding is in support of Hooyman [5] who said that, "Aged is abandoned by their family when the nursing homes assumed the responsibility for care or custody for them". Gill [4] opined that "In developing countries, aged are still cared for more in their homes than in institutions where abuse is easily identified. Actually, in African context, we embrace community system, where extended family lives together. May be this is why majority prefers to keep their aged at their homes instead of the nursing homes [8]. 
Hypothesis two: The hypothesis states that, "There is no significant impact of the social policy guiding the care of the elderly". The result analyzed from this hypothesis as calculated reveals that the percentage of those who disagreed that social policy guiding the care of the elderly in our Nation has significant impact is $66.7 \%$ to those who agrees to it that stands at $33.3 \%$. The null hypothesis is therefore accepted. Hence, there is no significant impact of the social policy guiding the care of the elderly in Nigeria. This discovery is similar to Durodola's [3] who says, “...The situation of old people's home in Nigeria is a world apart from what is obtainable in developed countries" [9].

Hypothesis three: There is no significant attention needed by the aged in terms of medical, social care and other services compared to children and pregnant women. This hypothesis reveals that respondents who agreed that aged people need medical, social care and other services as much attention as children and pregnant women would need are higher in percentage, compared to those who go against it. The percentage of those who supported the elevation of aged care is $59.7 \%$ while those against is $40.3 \%$. The null hypothesis is rejected. Hence the there is significant attention needed by the aged people in terms medical, social care, and other services compared to children and pregnant women as compared to the work of Durodola [3] which opined that," Lack of professional care giver is a serious problem for those old people who have chronic conditions and limitations on their ability to care for themselves and their homes [10].

\section{Conclusion}

Based on the findings, the present family neglect, social and health status of the elderly reveals that Nigerians have not come to realize the importance of taking good care of the aged. Many elders are roaming the street aimlessly, and have no hope for living. Many children have neglected their civic responsibilities towards their aged. Modernization and Urbanization has led most youths into neglecting their aged due to nature of their works. Also, a low level of social protection does often coincide with low levels of income and productivity. Therefore, it is very clear that a very large proportion of the aged population in Nigeria doesn't enjoy any social protection. This is as a result absence of a well defined policy on the care of the elderly [11]. However, it is discovered that due to our cultural belief, and attitude to aged homes, Nigerians don't yet know how to care for aged through Nursing homes. Another discovery shows that our policies in Nigeria are not adequate enough to take care of our aged in the society [12-14].

\section{Recommendations}

As long as these elders are alive, they require our attentions for their survivals. At one time or the other, these aged must have played vital roles in the building of our society. Therefore, we need to play our own part to make their lives meaningful. Therefore, the following recommendations are made to alleviate aged problems in our society:

A. There should be awareness about what aged stands for, their importance to the society, and their needs;

B. There should also be awareness about the modern day methods of caring for our elders in our society. Actually, our intimacy with our aged may not be eroded if adequate provisions are made to solve their problems, thereby reducing tension on family;

C. There is need for encouragement for establishment of more institutions that take care of the aged. More privately owned nursing homes should be encouraged;

D. Government monitoring of the presently owned institution must be encouraged, for better results;

E. Government policies on aged must have human faces. Pension must be paid as at when due, and elderly recreation centers must be encouraged;

F. Medical practitioners and social care gives should be encouraged to take up jobs at elderly nursing homes, and unskilled professionals be reduced to unskilled jobs alone.

\section{References}

1. Adebayo SA (1995) Institutional care of old people in Nigeria; A case Study of Lagos City Institution for the Aged.

2. Akukwe FN (1992) Senior Citizens; A Policy Dilemma. Veritas Printing and Publishing Press. Onitsha, Nigeria.

3. Durodola B (2007) A Gerontology hand book on Social work Practice.

4. Ellen Jaffe Gill LA (2008) Aging Process on Google.Com.

5. Hooyman N, Kyak HA (1996) Social Gerontology; A multi disciplinary perspective. Needlaan; Height; MA Allyn and Bacon publishing company. USA.

6. Kurtz RA (1960) Social work yearbook. New York National Association of Social Workers. New York.

7. Link Age 2000 (1998) Policy Implications of Global Aging.

8. Lowy (1991) Social Work with the Ageing. The Challenge and the promise of the Later Year prospect. Hills iL Waveland press. USA

9. Monk A (1990) Handbook of Gerontology Services. ( $2^{\text {nd }}$ edn), New York Colombia University Press, New York, USA.

10. United Nation (1994) The Elderly and Family in Developing Countries occasional paper series; No. 13. Vienna. New York, USA.

11. Lassey, Lassey (2001) Quality of Life for older people; An International perspective. New Jersey; PrenticeB Hall.

12. Kapur P (1997) Elderly abuse; Some counseling tips. Res Dev J 3(3): 1322.

13. World Health Organization (1998) Population Ageing-a Public Challenge. Fact Sheet No. 135, Geneva, Switzerland.

14. Olatunji TI (2010) Social Policy and the care of the elderly in Nigeria. 
Creative Commons Attribution 4.0

International License

For possible submission use the below is the URL

Your subsequent submission with Crimson Publishers will attain the below benefits

- High-level peer review and editorial services

- Freely accessible online immediately upon publication

- Authors retain the copyright to their work

- Licensing it under a Creative Commons license

- Visibility through different online platforms

- Global attainment for your research

- Article availability in different formats (Pdf, E-pub, Full Text)

- Endless customer service

- Reasonable Membership services

- Reprints availability upon request

- One step article tracking system 